\title{
Changes in Fractions of Urinary Free 17-OHGS before and after Operation
}

\author{
Tomihisa FUNYU, Shigenobu KUDO, Yasuo SHIRAIWA, \\ Yuriko TERAYAMA and Kazuo NIGAWARA \\ Department of Urology, Hirosaki University, School of Medicine, Hirosaki, Japan \\ (Director : Professor Tominisa Funyu, M.D.)
}

Ten patients who underwent various operations were examined in this study. Urinary total 17-OHCS and its fractions were determined with $\beta$-glucuronidase hydrolysis using thin layer chromatography. The method of analysis of fractions of urinary free 17-OHCS is outlined as follows: A 100 to $200 \mathrm{ml}$ aliquot of 24 hour urine was extracted with dichloromethane without hydrolysis. The oillike low polar impurity was removed using column chromatography. The steroids were dissolved from column with ethanol and evaporated. The next process is exactly the same as the determination of total 17OHCS. The recovery in this method was $72 \%$ on the average as in the fractions of total 17-OHCS. The following results were obtained.

The excretion volume of individual fractions of urinary free 17-OHCS was about $0.05 \mathrm{mg} /$ day before operation. After operation, free comp. $\mathrm{F}$ increased significantly. In addition there was alimit to the amount of excretion of free comp. E, THF and THE. However, the excretion volume of THE in total evidently exceeded the other three fractions before operation. After operation, individual fractions increased in the following ascending order, THE, THF and comp. F, varying with the degree of stress. Therefore, the excretion pattern of fractions of urinary free 17-OHCS was quite different from that of fractions of total 17-OHCS that were hydrolized with $\beta$-glucuronidase.

The excretion volumes of free comp. $F$ and comp. $E$ were several tens percent of comp. $\mathrm{F}$ and comp. E calculated as fractions of total 17-OHCS. However, the excretion volumes of free THF and THE were only a few percent of THF and THE calculated as fractions of total 17-OHCS. It is clear that comp. F and comp. E are also conjugated with glucuronic acid though the degree of conjugation is much lower than their metabolites, THF and THE.

After operation, the above mentioned percentage increased in free comp. $\mathrm{F}$ and comp. E, while it decreased in free THF and did not change in free THE. It is clear that the rate of conjugation of free comp. $\mathrm{F}$ and comp. $\mathrm{E}$ with glucuronic acid diminish compared with control, and that the metabolism of cortisol shifts to THF pathway during surgical stress.

(See pp. 432 442) 


\title{
手術侵襲時における尿中遊離型 17-OHCS 分画の変動
}

\author{
弘前大泌尿器科（主任 : 舟生富寿教授） \\ 舟 生 富 寿, 工 藤 茂 宣 \\ 白岩 康 夫, 寺山百合子 \\ 二川原和 男
}

（昭和 47 年 5 月 10 日受付）

手術前後の尿中遊離型 17-OHCS 分画，および $\beta$-glucuronidase 加水分解による総 17-OHCS 分画 を測定した，遊離型分画の術前值は 4 分画とも $0.05 \mathrm{mg} / \mathrm{day}$ 前後のほぼ均等量を示し, 術後は comp. $\mathrm{F}$ の増加が特徴的で, 総量分画とは量的, 質的に全く異なる排泄パターンを呈した，遊離型各分画のそ れぞれの総量分画に対する割合は，comp. F, comp. E は数10\%を占めたが，THF，THE は数\%にす ぎなかつた. comp. F, comp. E のグルクロン酸抱合が明らかであつた。

\section{緒 言}

血中における corticosteroids は蛋白と結合した遊離型, 蛋白と結合しない全くの遊離型, 抱合型の3つ の型で存在するととは一般の認めるとてである1).すなわち活性型である 遊離型は $\alpha$-globulin，一部は albumin と結合して肝における代謝, 腎よりの垡失を防いでいるとされているが23)，手術侵襲により biological active な nonprotein bound cortisol 濃度は20倍にも著增するてとが浜中")，魚住ら れている。代謝された cortisol, cortisone は THF, THE のように tetrahydro 型として大部分はグルクロ ン酸と，一部は硫酸と抱合して尿中に排泄される1．したがつて尿中 17-OHCS の測定で, $\beta$-glucuronidase によるグルクロン酸抱合の加水分解による測定法では，抱合をうけない corticosteroids およびその代謝型 も含まれており，てれらの総量は別個に加水分解を行なわずに測定され，普通尿中遊離型 17-OHCS とさ れている. しかし，その24時間排泄量は微量であり，それらの分画量てついての報告は本邦では全く見あた らない.

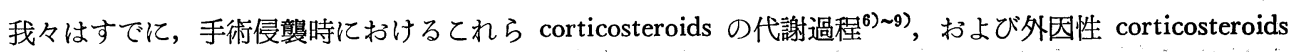
の尿中排泄パターン10)11) 亿ついて報告してきたが，その過程で尿中遊離型 17-OHCS 分画の量的, 質的変 動は如何という点の解明の必要を感し，手術前後についててれらの測定を行ない, 総量分画との比較検討も 行ない，興味ある知見を得たので報告する。

\section{I 検索対象および方法}

泌尿器科入院患者中, 原則として全身麻酔のもとに手術が行なわれた尿管結石症 2 , 腎結石症 2 , 膀胱癌 3 , その他 3 の計10例で，21才から75才までの男子 5 例，女子 5 例を対象とした。.いずれも肝機能は正常で, 副 腎皮質ホルモンの投与歴はない．採尿方法は原則として手術数日前までに午前 5 時より 24 時間，対照尿を採 取しておき，手術後の尿は患者が手術台上に登つた時刻（全例午前10時頃）より正確に24時間 (op. 1 と略) 採取し，手術操作により術中の尿が失われる例では，手術終了後より蓄尿を開始した。1例については，術 後48時より72時まで（op. 3 と略）と手術第 7 日目（op. 7 と略）の 24 時間尿も採取した。 以上の検索尿に ついて，尿中総 17-OHCS 量とその分画量, および遊離型 17-OHCS 量とその分画量 (comp. F, comp. E, 
THF，THE) を測定した.

尿中 17-OHCS の総量, 遊離型量, 総量の分画の測定法については, すでに舟生ら ${ }^{12)}$ 寺山ら ${ }^{13)}$ が報告し ているので省略する。ただし，遊離型 17-OHCS 分画の測定にあたつては，1日排泄量がきわめて少ない ので通常測定のほほ10倍にあたる24時間尿の 100〜200 $\mathrm{ml}$ （ほぼ1/10日尿）を使用した。抽出操作後の薄層 chromatography を行なう場合, 用いる尿が多量なため油状物質の混入が著しく, 薄層への spotting に支 障をきたすためての極性の低い夾雑物を column chromatography により排除した. この方法は, 内径 $6 \mathrm{~mm} の$ column に Silica Gel (100mesh 以上) $1.5 \mathrm{~g}$ を benzen : ethylacetate (85:15) の混合溶媒を 用い湿式で充媜し，てれに同じく benzen : ethylacetate (85:15) の混合溶媒 $3 \mathrm{ml}$ に溶解した尿抽出物を 通した. 抽出物を完全に column に移すためのとの操作は 3 回繰り返した. 溶液が通過した後, ての colu$\mathrm{mn}$ を上述と同じ混合溶媒 $30 \mathrm{ml}$ で洗涤し, 流出液は捨てる。乙の中には $\mathrm{C}_{19} \mathrm{O}_{2}-17-\mathrm{KS}$ 程度の極性をもつも のまでが含まれているはずである ${ }^{14)}$. 次いで, column から ethanol $30 \mathrm{ml}$ で溶出し, てれを遊離型 17OHCS 分画測定の試料として減圧下, $60^{\circ} \mathrm{C}$ 以下で蒸発乾固した. てれ以後の操作は 17-OHCS の総量の分 画と全く同様に行なつた。乙の方法における回収率は総量の分画測定の際とほぼ同じく72\%であつた。した がつて, Silica Gel column chramatography そおける 17-OHCS の回収率の低下はほとんど無視し得た. 検出の下限界については, 使用する尿の量を変化させることができるので明確に規定するととはできない. 機峨的には, 最終測定試料中の濃度で $0.2 \mu \mathrm{g} / \mathrm{ml}$ 以上ならば一応検出可能であり, 遊離型 17-OHCS 分画 の測定に使用する尿量としては通常 100〜200ml を必要とした.

検索10例については，全身状態，手術術式，手術時間，出血量などより侵襲の軽重を推測し，Table 1の

Table 1. Subjects, operations performed and other data.

\begin{tabular}{|c|c|c|c|c|c|c|c|}
\hline Case & Name & $\begin{array}{l}\text { Age, } \\
\text { Sex }\end{array}$ & Diagnosis & Operation performed & $\begin{array}{l}\text { Ope. time } \\
\text { (hr., min.) }\end{array}$ & $\begin{array}{l}\text { Blood loss } \\
(\mathrm{ml})\end{array}$ & $\begin{array}{l}\text { Anes. time } \\
\text { (hr., min.) }\end{array}$ \\
\hline 1 & A.O. & $23, \mathrm{~F}$ & $\begin{array}{l}\text { 1t. ureteral } \\
\text { stone }\end{array}$ & 1t. ureterolithotomy & 1,20 & 112 & 1,40 \\
\hline 2 & R.A. & $21, F$ & $\begin{array}{l}\text { rt. ureteral } \\
\text { stone }\end{array}$ & rt. ureterolithotomy & 1,25 & 150 & 1,50 \\
\hline 3 & S .M. & $39, \mathrm{M}$ & rt. renal stone & rt. nephrectomy & 2,00 & 395 & 2,30 \\
\hline 4 & S.S & $63, \mathrm{M}$ & 1t. renal stone & 1t. nephrectomy & 2,15 & 785 & 3,50 \\
\hline 5 & $\mathrm{~S} . \mathrm{K}$. & $44, \mathrm{M}$ & 1t. renal tbc. & 1t. nephrectomy & 1,35 & 260 & lumbar \\
\hline 6 & S.I. & $32, \mathrm{~F}$ & $\begin{array}{l}\text { rupture of rt. } \\
\text { renal pelvis }\end{array}$ & $\begin{array}{l}\text { transperitoneal } \mathrm{rt} . \\
\text { nephrectomy }\end{array}$ & 3,10 & 1000 & 5,50 \\
\hline 7 & S.Y. & $36, \mathrm{M}$ & vesical cancer & $\begin{array}{l}\text { trial of total cystectomy } \\
\text { bil. ureterocutaneostomy }\end{array}$ & 2,50 & 550 & 3,50 \\
\hline 8 & N.M. & $71, \mathrm{M}$ & $\begin{array}{l}\text { lt. ureteral } \\
\text { cancer }\end{array}$ & $\begin{array}{l}\text { 1t. total nephroureterect- } \\
\text { omy, partial cystectomy }\end{array}$ & 5,10 & 1214 & 6,30 \\
\hline 9 & T.T. & $39, \mathrm{~F}$ & vesical cancer & $\begin{array}{l}\text { making of artificial blad- } \\
\text { der by ileal loop with bil. } \\
\text { ileoureterostomy }\end{array}$ & 8,05 & 2000 & 9,40 \\
\hline $10^{*}$ & K.K. & $75, \mathrm{~F}$ & vesical cancer & $\begin{array}{l}\text { total cystectomy, bil. } \\
\text { ureterocutaneostomy }\end{array}$ & 3,30 & 800 & 4,55 \\
\hline
\end{tabular}

$* 200 \mathrm{mg}$ of cortisol was intravenously administered during operation. 
ごとく軽度例より高度例へと羅列し，乙れらをその侵襲程度の類似性より便宜上，I 群〜IV群に分類して観 察した.

\section{II 検 索 成 績}

\section{（1）尿中遊離型 17-OHCS 量および総 17-OHCS 量の変動}

Fig. 1 に示すごとく, 遊離型 17--OHGS 量は総 17-OHGS 量の増減にほとんど一致した変動を示してい

Fig. 1. Changes in urinary free and total 17-OHCS before and after operaton.

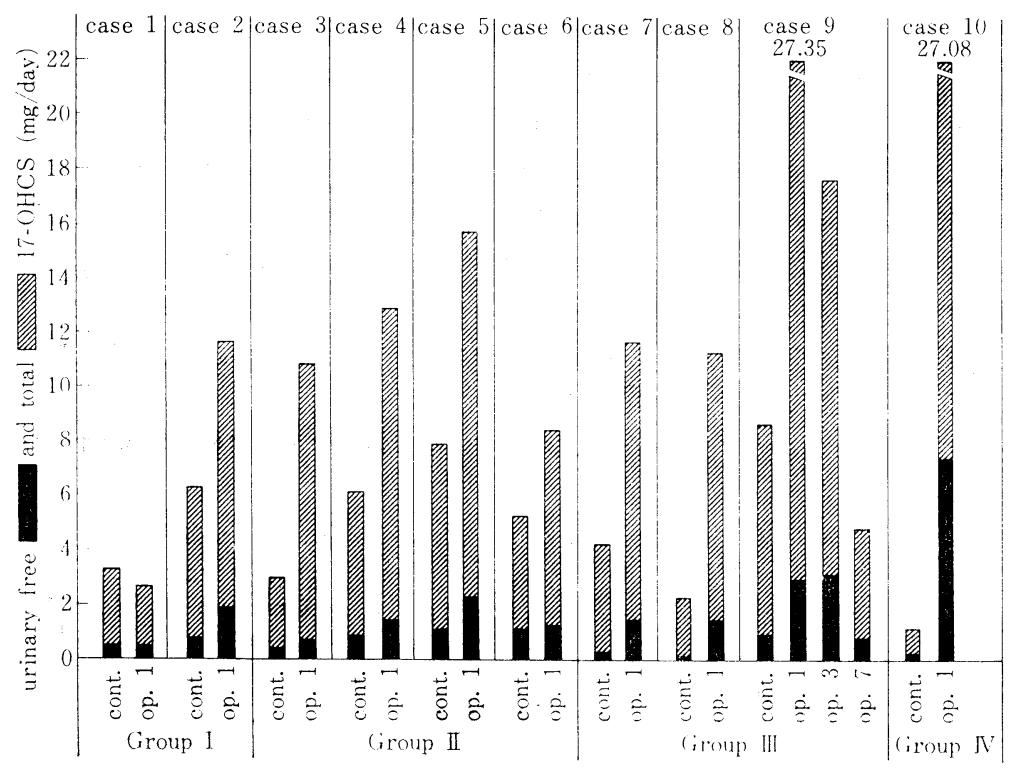

All cases were classified into four groups according to the degree of stress estimated from such data as method of operation and operation time.

Abbreviation : cont. ; control. op. 1 ; from beginning of operation to $24 \mathrm{hrs}$. op. 3 ; from $48 \mathrm{hrs}$. to $72 \mathrm{hrs}$. op. 7 ; on the 7 th day.

る.すなわち, 個々の症例における臨床状態を考慮した観察では, case 1, 尿管切石術例では対照值の総量 は $3.33 \mathrm{mg} /$ day (以下すべて単位は $\mathrm{mg} / \mathrm{day}$ でてれを省略) に対し，遊離型は0.500（総量の $15 \%$, 以下カ ッコ内同じ）であり，op. 1 では総量 2.66 亿対し遊離型は0.47（17\%）であり，ての例では op. 1 以降に最 大反応が示されたものと考えられる. 同じ術式の case 2 では対照值の総量は 6.29 と高值を示したが，対 照尿採尿時に偶然検查のためヒマシ油投与, 高圧浣腸が 2 回行なわれている。遊離型は0.77（12\%）で，続 いて op. 1 で遊離型は $1.80(15 \%)$ と増加した。腎摘除術の case 3 では対照值は $0.42(14 \%)$ op. 1 で $0.65(5 \%)$ を示した. 同じく腎摘除術の case 4 では対照值は6.23 と0.92（13\%）で高值を示したが，臨 床状態に特に 皮質機能 をえ進させる因子はみあたらなく，op. 1 で $1.42 （ 10 \%)$ に排泄量が増加した。同 じく case 5 では対照值は7.93と1.15（14\%）と高值を示したが前例同様, 臨床状態に変化はなく採尿も手 術 3 日前に行なわれている. op. 1 で2.25（14\%）に増加した。 経腹膜的腎摘が行なわれた case 6 では, 対照值は5.31 と1.16 (21\%) と高值であるが，腎盂破裂による持続的な右側腹痛と著明な筋性防禦が存した。 op. 1 で1.27（14\%）飞増加した. 膀胱全摘術の試みと両側尿管皮膚瘻術が行なわれた case 7 では対照值 は0.37（ $8 \% ）$ が op. 1 で1.52（13\%）となつた. 経腹膜的腎尿管全摘除術と膀胱部分切除の case 8 では $0.06(2 \%)$ が op. 1 で1.43（12\%）に増加した. この例は，手術開始 5 時間後より蓄尿を開始している. 
膀胖全摘除術 1 年 6 ケ月後に回腸による代用膀胱造設術を行なつた case 9 では対照値は8.73 と0.97 (11\%) で対照值としては著明な高值であるが，両側尿管にカテーテルを挿入し，採尿袋を装着している他発熱など はみられていない，op. 1 で27.35と2.91（10\%）を示した。前例同様，手術開始 8 時間すぎより24時間著 尿を開始している. case 10 は膀胱全摘除術中 shock に宿いり, $200 \mathrm{mg} の$ cortisol が静注されている. 対照值は0.27 (12\%) が op. 1 で7.40 (27\%) の排泄量を示した.

小括 10 例における尿中遊離型 17-OHCS の排泄量は対照值で 0.06〜1.16 の範囲の排泄を示し, 総量に 対する割合は 10 例中 7 例が $12 \%$ 15\%の範囲であつた. 手術第 1 日目では 1 例を除き 9 例て対照値以上の排 泄量の增加がみられ，総量の増减にほとんど一致した。総量に対する割合は内因性のみの 9 例中 7 例が $10 \%$ 〜15\%の範囲を示し，対照時とあまりかわらなかつた．ただし，術中外因性に $200 \mathrm{mg} の$ cortisol を静注し た1例のみは総量の $27 \%$ 遊離型として排泄した。

\section{（2）尿中遊離型 17-OHCS 分画および総 17-OHCS 分画の変動}

4 群に分類した前述10例の分画測定値を comp. F (以下 F と略), THF を縦軸に， comp. E (以下Eと 略), THE を横軸にとり座標として表わし，観察した。

まず尿管切石術の I 群では Fig. 2 に示すでとく case 1 の遊離型の対照值はF は 0.022 (総量分画中の F

Fig. 2. Changes in fractions of urinary free (above figure in each case) and total (lower figure in each case) 17-OHCS before and after operation.

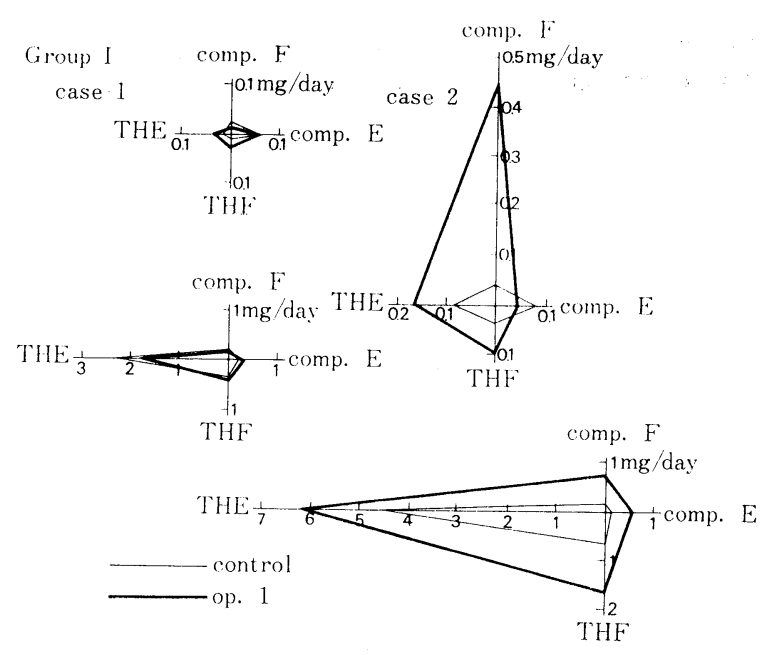

The rhombus of free fractions extended to comp. F ordinate. However, it extended to THE abscissa in total fractions.

の13\%)，Eは0.06(総量分画中の $\mathrm{E} の 30 \%$ )であり，てれらの tetrahydro 型である THF は0.006 (総量分 画中の THF の 2\%), THE は0.016(総量分画中の THE の1\%, 以下同様) と 0.06 以下の小スケールの 不整の菱形を示した。一方, 対照時の総量の分画は THE 方向延長のパターンを呈している. op. 1 では遊 離型は F 0.019 (15\%), E 0.071 (22\%) 飞対し THF 0.029 (1\%), THE 0.033 (2\%) と総量の分画か変 化がないのと同様，排泄量において対照時とほとんど変化がなかつた。 case 2 では対照值は F 0.036 (45\%), E $0.079(60 \%)$, THF $0.040(7 \%)$, THE $0.086(2 \%)$ と排泄量では 4 分画とも 0.05 前後のほぼ均等な排泄 
Fig. 3. Changes in fractions of uriuary free (above figure in each case) and total (lower figure in each case) 17-OHGS before and after operation.

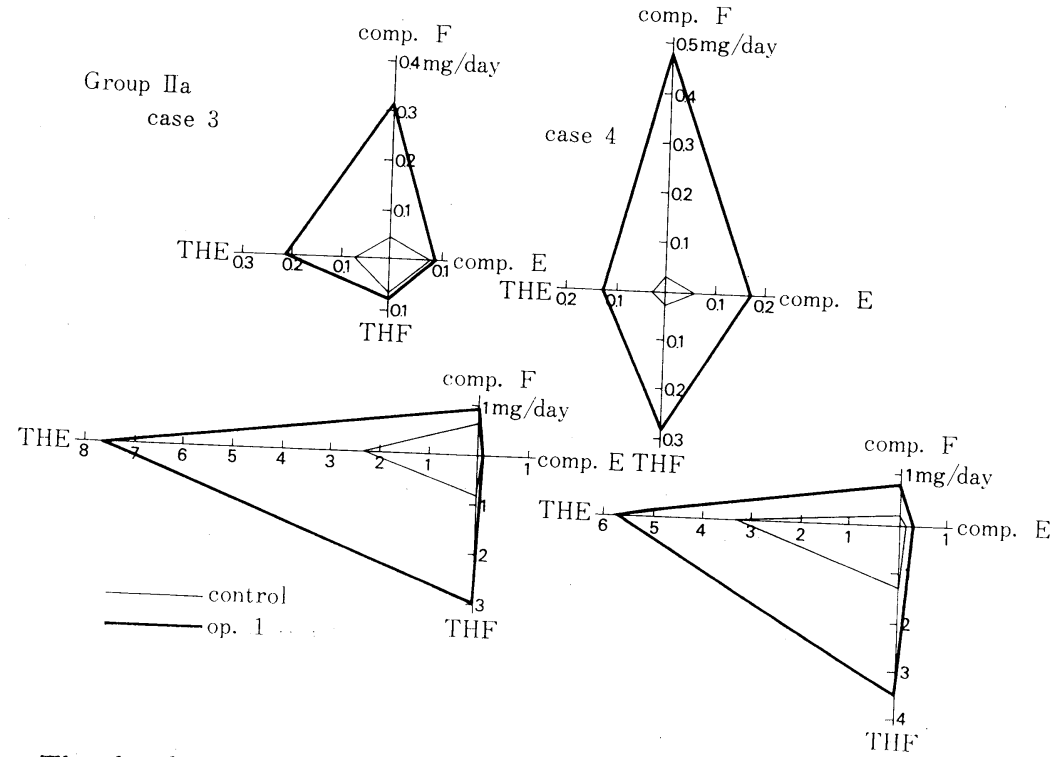

The rhombus extended to comp. $F$ ordinate in free fractions. However, it extended to THE abscissa and THF ordinate in total fractions.

Fig. 4. Changes in fractions of urinary free (above figure in each case) and total (lower figure in each case) 17-OHCS before and after operation

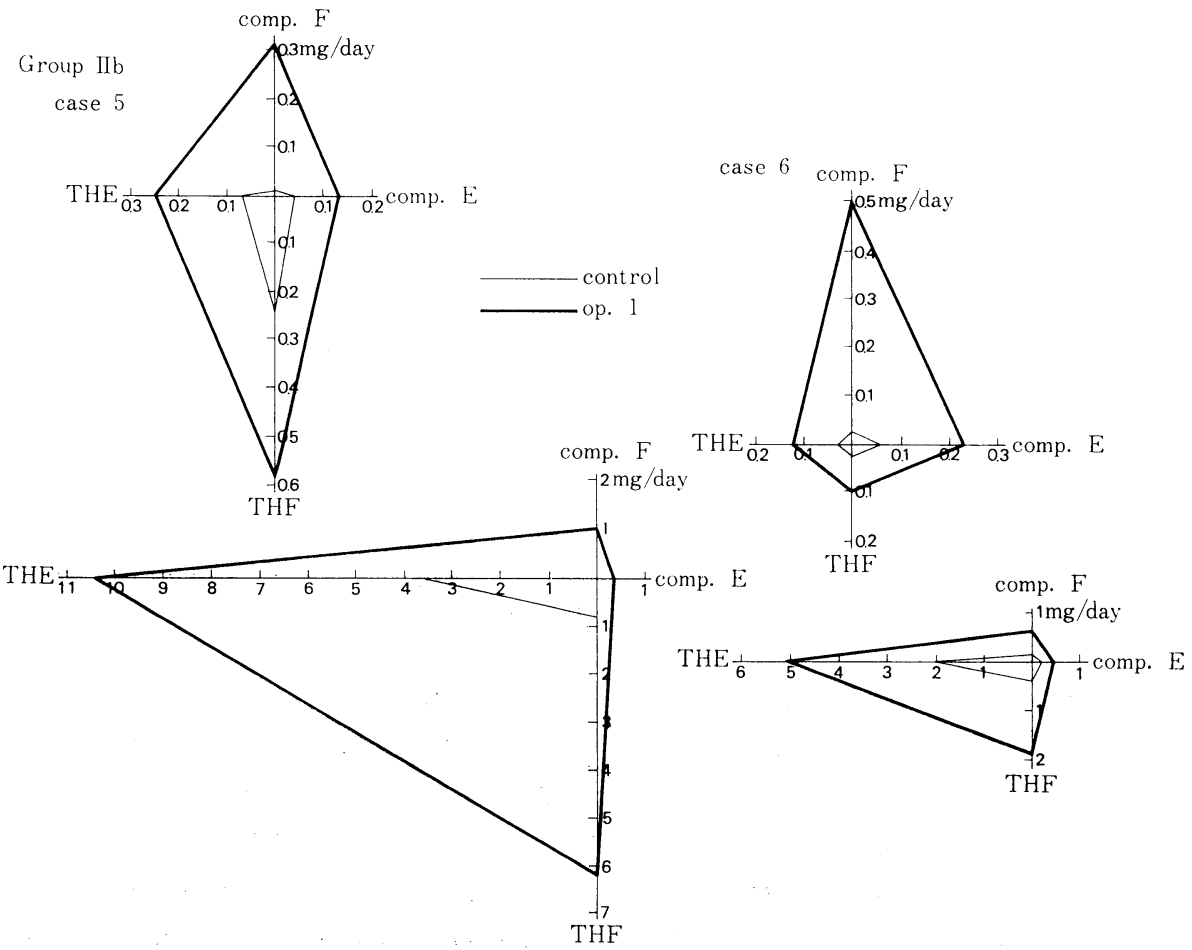

Almost same tendency as Group IIa. 
量を示した。しかし， 総量分画に対する割合では F， E とてれらの tetrahydro 型では明らかな差異がみら れた。 op. 1 では，Fは $0.462(67 \%)$ と著増，Eは0.044（7\%) と対照值より低く測定され，THF は $0.094(5 \%), \mathrm{THE} は 0.071(2 \%)$ を示し， F 方向へ著明に延長したパターンを呈した。一方総量分画は THE 方向へ最も延長している, 総量分画住対する割合はFが67\%に著増したが, THF は軽度减少, THE は不変である。

腎摘除術よりなるII群の成績は Fig. 3，4，亿示した。 case 3 では対照值は F 0.043 (6\%)，E は0.079 と 総量分画より高値に測定され, THF $0.072(9 \%)$, THE $0.072(3 \%)$ と 4 分画のほほ均等な菱形を呈した. てれが op. 1 ではFは $0.316(33 \%)$ 亿増加，Eは 0.088 と総量分画より高く, THF 0.074 (3\%), THE $0.213(3 \%)$ と F 方向へ最も, 次いで THE 方向へ延長したパターンを示した. 総量分画に対する割合は, F は增加, THF は減少, THE は不変である。, 一方, 総量分画パターンは, THE, 次いで THF 方向へ延 長している。 case 4 では対照值は F 0.032 (16\%), E 0.064 (53\%) 亿対し THF 0.031 (2\%), THE 0.027 (1\%) と小スケールの菱形を呈した。op. 1 では F は $0.490(60 \%)$ と排泄量, 総量分画に対する割合とも に著增し, Eは $0.177(66 \%)$, THF は $0.286(8 \%)$, THE は0.129（2\%）と排泄量において少しく増加 し, パターンはF方向へ最も, 次いで THF 方向へ延長した。一方, 総量分画は THF の増加量が THE のそれとほぼ等しくなつている. case 5 では対照值パターンは THF 方向へ延長しており，F 0.010, E 0.040, THF 0.250 (32\%), THE $0.070(2 \%)$ であつた。 てれが op. 1 では F 0.310 (32\%), E 0.130 (45 \%), THF $0.590(10 \%)$, THE $0.250(2 \%)$ と THF 方向へ最も, 次いでF方向へ延長したパターンを呈 した，総量分画に対する割合は，THF は減少，THE は不変である，総量分画のパターンは THF の増加 量が THE のそれに近接している. case 6 では対照值は 0.028 (22\%), E 0.060 (33\%), THF 0.023 (6\%), THE $0.037(2 \%)$ とほぼ芷菱形の小スケールパターンを呈したが，乙れまでの例と同様，F， Eとそれら の tetrahydro 型とでは総量分画に対する割合は明らが異つている。op. 1 では F は0.502（76\%）と排泄 量, 総量分画に対する割合ともに著増, Eは0.228 (57\%) と, 共に増加した。 THF は 0.098 (5\%), THE は0.126 (2\%) と排泄量の僅少増加がみられるが総量分画に対する割合は THF がわずかに減少, THE は不変であり, $\mathrm{F}$ 方向へ最も, 次いが $\mathrm{E}$ 方向へ延長したパターンを呈した。一方, 総量分画のパターンは THE の排泄量, 増加量が最大で，むしろ I 群の最も軽度の侵襲のパターンを呈している.

III群の成績は Fig. 5 亿示した。 case 7 では対照值は F 0.074 (57\%), E 0.088 (88\%), THF 0.009 (1\%), THE $0.070(2 \%)$ と THF を除く 3 分画はほぼ均等な值を示した。 op. 1 では, F 0.149 (41\%), E 0.483

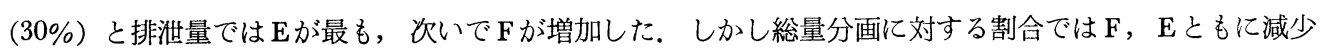
している. 次いで THF は 0.263 (9\%), THE は0.163（3\%）と排泄量が少しく増加したが, 割合も増加 し全体として E 方向と F方向へ延長したパターンを呈した。一方, 総量分画のパターンはII群とあまり変ら ないが，Fが1.0を超えている点でII群とは異なる， case 8 では，対照值は測定不能であつた。 op. 1 は Fは $0.646(60 \%)$ と内因性の 9 例中排泄量で最高值を示し, Eは $0.089(22 \%)$, THF は $0.126(3 \%)$, THE は0.079 (1\%) とF方向にのみ著明に延長した。 一方, 総量分画では THF は THE に近接し，F は1.0を超えている。 case 9 では対照值はFは 0.027 (54\%), Eは 0.106 (22\%), THF は $0.011(2 \%)$, THE は0.042 (1\%) であり。op. 1 ではFは $0.453(30.0 \%), \mathrm{E} は 0.453(45 \%)$ と, 排泄量では增加し ているが総量分画に対する割合では F は減少，Eは增加している。 THF は $0.144(2 \%)$, THEは 0.155 （1％）と排泄量で僅少の増加を示すも，総量分画に対する割合では変化が全く示されなかつた，次いで op. 3 ではFは 0.599 (90\%)，Eは0.508（63\%）と排泄量, 総量分画に対する割合においても增加し, 一 方 THF は 0.295 (10\%), THE は $0.189(2 \%)$ と排泄量において少しく増加している. op. 7 では Fが 最も減少している。他方総量分画では op. 1 ではFは1.51, E は 1.01, THF は 7.27, THE は 15.15, と きわめてスケールの大きいパターンを示している.

IV群の成績は Fig. 6 亿示した. case 10は膀胱全摘除術中に200mgの cortisol か清注されている. 対照值 はFは $0.042(38 \%)$, Eは $0.065(20 \%), \mathrm{THF}$ は $0.042(9 \%), \mathrm{THE}$ は $0.037(3 \%), と 4$ 分画のほほ 
Fig. 5. Changes in fractions of urinary free (above figure in each case) and total (lower figure in each case) before and after operation.

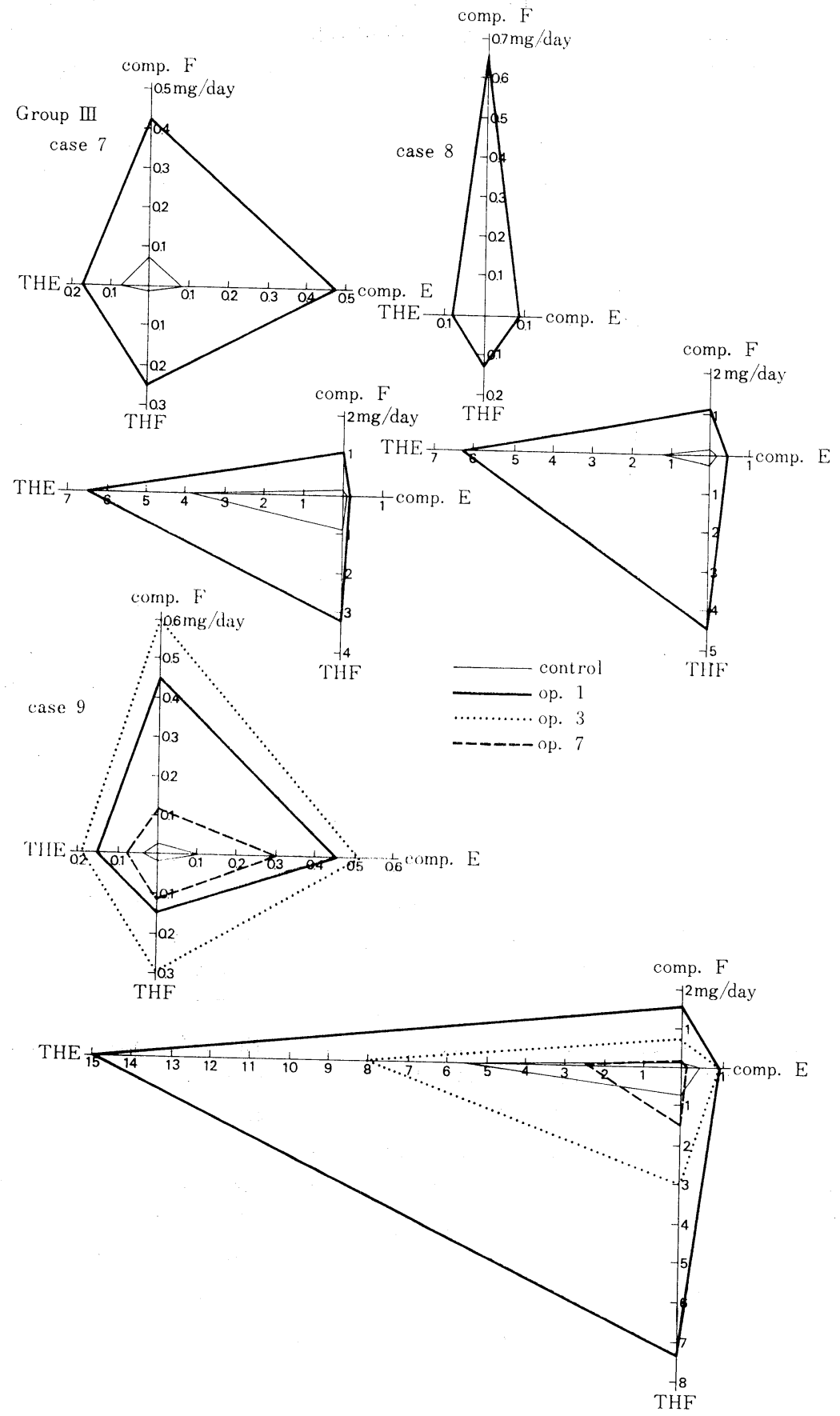

The rhombus extended to comp. F ordinate and comp. E abscissa in free fractions. However, it extended to THF ordinate more evidently than Groups I and II in total fractions. 
Fig. 6. Changes in fractions of urinary free (left figure) and total (right figure) 17-OHCS before and after operation.

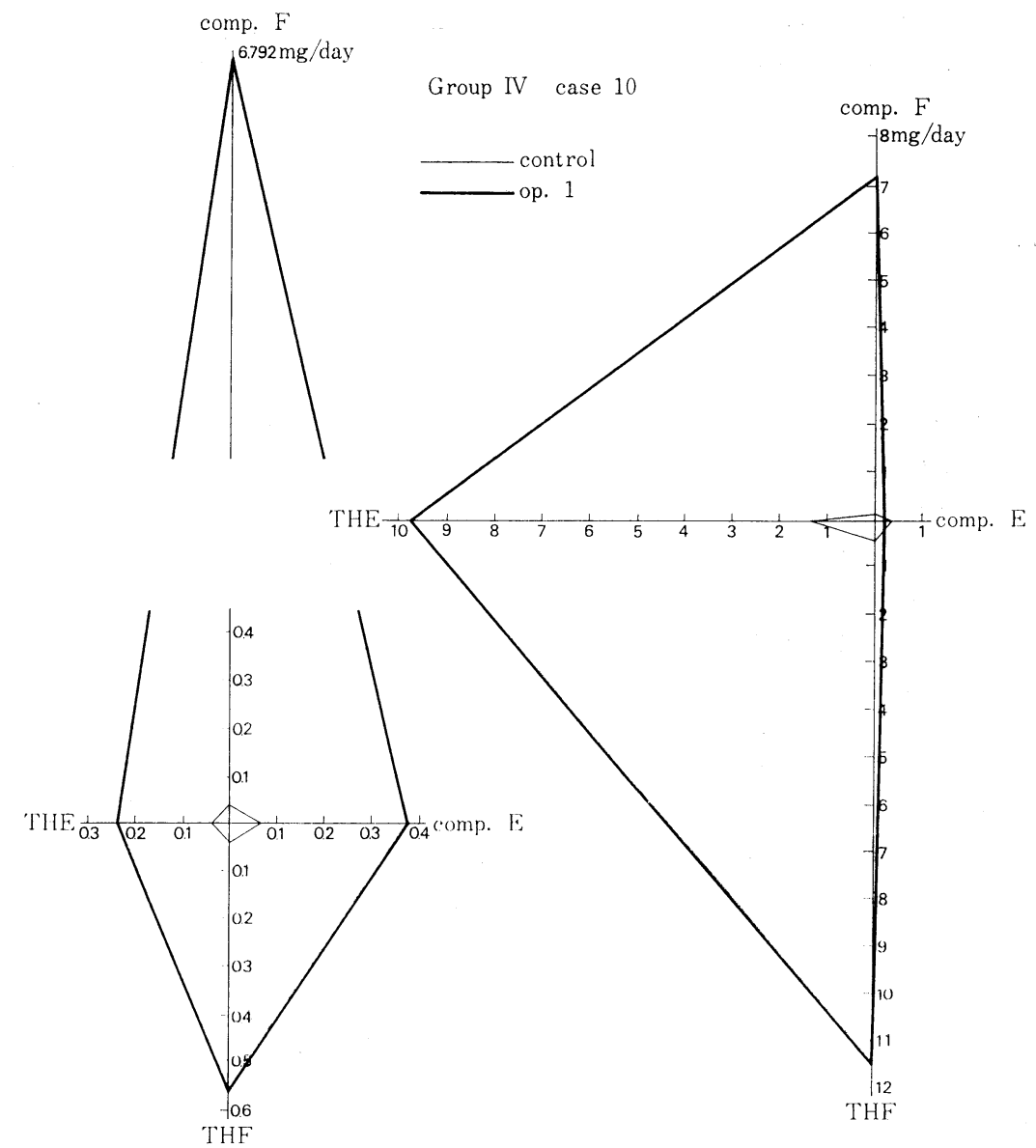

$200 \mathrm{mg}$ of cortisol was intravenously administered during operation. The rhombus of free fractions extended strikingly to comp. $F$ ordinate and the excretion volume of the other three fractions is limited. On the other hand it extended strikingly to comp. F and THF ordinates in total fractions.

均等な排泄量を示している。 op. 1 では F は 6.792 (95\%) と驚異的な排泄量を示し，総量分画に対する割 合でも10例中最大值を示した， Eは 0.380 と総量分画よりも高値に測定されている。一方，THFは 0.570 (5\%), THE は $0.238(2 \%)$ と, 排泄量, 総量分画に刘する割合ともに, 他の 9 例とほとんど変りない値 を示しているのが注目される。他方, 総量分画は THF は 11.55, THE は9.82と, THF>THEとなり, Fは7.40ときわめて高值を示した。 $\mathrm{E} は 0.190$ 排泄をみたにすぎない.

小括 対照時における尿中遊離型 17-OHCS 分画の排泄量は, 4 分画とも0.05 前後のほぼ均等量の排泄 を示した，手術第 1 日尿では，4 分画ともに排泄量の増加がみられたが，F は手術侵襲の程度にほぼ相関し て増加， Eも相関して増加する傾向を示したが，0.5程度に排泄量の限界が存した. THF, THE, は侵襲程 度および外因性の cortisol 注入にはほとんど関係せず，それぞれ $0.25 ， 0.6$ 程度に限界がみられた。術後の パターンは, 特に F 方向の延長が特徴的であり, 術前後のいずれにおいても総量分画の排泄パターンとは量 
的，質的に全く異つていた。

遊離型 4 分画のそれぞれの 総量分画排泄量に 対する割合は，F は は対照時では 6 57\% (大部分は13〜54 \%) の範囲が op. 1 では15〜76\%（大部分は32〜67\%）の範囲で，ほとんどの例が増加し，特に cortisol 注入例は $95 \%$ を占めた，Eは対照時は 20〜88\% をしめ，op. 1 では 7 301\%の範囲を示し大部分が術後の 割合が増加した。（しかし，測定し得た20検体のEの測定值中 5 検体が対応する総量分画值よりも高値に測 定された）一方，乙れらの代謝型では THF は対照時では 1 32\%（大部分は 2〜9\%）の範囲が，op. 1 では $1 \sim 10 \%$ （大部分は $2 \sim 8 \%$ ）の範囲で，対照值不明の 1 例を除き 9 例中の 6 例が総量分画に対する 割合が軽度减少した。 とてろが THE は対照時 op. 1 ともに全例 1 〜 $3 \%$ 範囲で術後の割合の変化はみ られなかつた。

\section{III 総括ならびに考按}

尿中遊離型 17-OHCS 分画に関しての報告は，外国文献が散見されるのみでほとんどみあたらない ${ }^{15}$ 16). 我々は微量の排泄量をより正確に測定するために，用いる尿量を100〜200 ml とし夾雑物を column chromatographyにより除去した．それでも E の20中 5 検体，Fの20中 1 検体に遊離型值が総量分画値よりも高值 に測定されている．乙れは寺山ら ${ }^{13)}$ が報告しているごとく，我々の教室における総量分画の回収率は 58 ～86 であり，一応平均回収率を $72 \%$ として補正しているため，総量分画測定の際の実際の回収率が遊離型分画 （平均回収率72\%）測定の際の実際の回収率を下まわつた場合にはこのようなととが起り得ると考学られる.

遊離型 17-OHCS 量は総 17-OHCS 量とは一定の比例関係はないとする報告もみられるが彷，我々の成 績では総量の変動によく一致し，工藤ら ${ }^{6) \sim 99}$ の報告と同じ結果である．ただし，尿中に存在する $\beta$-glucuronidase に上る水解も考慮されねばならないが，栘屋，加藤ら ${ }^{18)}$ は平均 $556 \pm 140$ 単位/ $\mathrm{dl}$ とし，東 ${ }^{19}$ は午前中 に高く, 午後に低いとしている.我々の測定法では, 総量分画の測定には尿 $20 \mathrm{ml}$ に対し6400単位を加えており, かつ至適 $\mathrm{pH}$ を 4.6 としているので尿中 $\beta$-glucuronidase による遊離型量への影響は重視していないが，詳 細な検討は行なつていない，遊離型の総量分画に対する割合は対照時で $12 \sim 15 \%$ で手術侵襲後も排泄量は增 加したが，割合はほとんど変らず，工藤ら ${ }^{6) \sim 9)}$ の術前後のデータを計算してみても最高度の侵襲(例を除き同 様であつた。しかし，術中にさらに cortisol を注入された例では著明に割合が増加した。乙れらは Daughaday $ら^{2)}$ ，田村 ${ }^{20)}$ が述べているごとく，血中 cortisol 濃度が増加するにつれ，血中での遊離型の占める割 合，尿中への排泄が増加するとは言え，舟生ら ${ }^{1011}$ が報告しているでとく，侵襲時では血中レベルの上昇に もかかわらずそれらが肝における代謝容量の範囲内であれば代謝型として排泄され，代謝容量か泿界に達し た時点では代謝型の排泄量が限界に達して cortisol のみの排泄が著増するとする意見に合致し，ある程度 の血中 cortisol 濃度までは総量と遊離型はほぼ一定の割合で排泄されるものと考えられる.

さて，尿中遊離型 17-OHCS 分画の排泄量であるが，刘照時では 4 分画とも 0.05 前後のほほ均等量の排 泄を示し, 舟生 ${ }^{12) 21)}$, 寺山ら ${ }^{13)}$, 工藤ら ${ }^{6) \sim 9)}$ が非ストレス時での総量分画の排泄量は THE が最大, 次い で THF とし，F とEは1.0以下の僅少量であると報告しているのに対比し，全く異なる排泄パターンを呈 した。 また，その総量分画に対する割合は $\mathrm{F} ， \mathrm{E}$ は数10\%を占めるに反し，それらの tetrahydro 型は数\% にすぎなかつた，したがつて，F，Eが代謝されて尿中に排泄される過程で THF，THE が一部グルクロ ン酸抱合を受けずに排泄されることが明らかであり，Weichselbaum \& Margraf ${ }^{22}$ が血中遊離型 THE を証 明しているととからもうなずかれる。乙れら遊離型の tetrahydro 型が総量分画量の数\%にすぎないのはグ ルクロン酸抱合の意義から言つても，むしろ当然であろう。しかし，F，Eが肝による代謝，腎よりの再吸 収を受けず遊離型のまま一部尿中に排泄されるとしても，てれらが $\beta$-glucuronidase で水解された総量分画 量と同量ではなくその数10\%を占めるということは F，Eが一部グルクロン酸抱合を受けて排泄されている ことの証左であると考えられる. Brovillet \& Mattox ${ }^{16)}$ は正常人の尿中遊遊型 cortisone $57 \mu \mathrm{g} / 24 \mathrm{hr}$, cortisone glucuronide $63 \mu \mathrm{g} / 24 \mathrm{hr}$, 同じく cortisol 19, cortisol glucuronide 25 と述へ, cortisone, cortisol はG-21で グルクロン酸抱合されるとしている。我々の検索では抱合部位の決定はできないが，化学構造上最も可能性 
のある部位として 1 級水酸基を有する G-21が考えられ，次いで 2 級水酸基を有する G-11 であり，G-17は ほとんど可能性がないと考えている。

手術侵襲後における遊離型分画の変化は 4 画とも排泄量の増加をみたが，Fが最も侵襲程度に相関して増

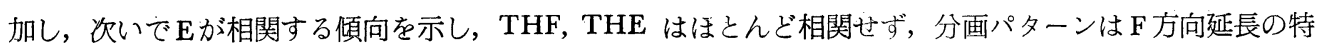
徵的なパターンを呈した。 また F 以外の 3 分画には排泄量の限界が存在した．てれらは工藤ら ${ }^{6) ~ 9) ~}$ 総量分 画の成績で侵襲軽度の例より高度の例へと THE, THF, F の順に増加順位が存するとする成績とは異つて おり，遊離型分画中では Fと Eが主体をなし，AGTH 負荷により，主としてFが著増したとする Kornel \& Richardson ${ }^{15)}$ の報告と一致する.ただし, 遊離型分画中で F 以外の分画に排泄量の限界が存在したととは, 総量分画の成績と同様である. 本稿中 case 8, case 9 の総量分画中の F 值がその侵襲のわりには我々がす でに報告した成績に比し低いのは，乙れらが手術操作のため $5 〜 8$ 時間後より 24 時間蓄尿を開始しているた めと考えられ，実際は遊離型の $\mathrm{F}$ と少しく高值ではなかつたかと考えられる.

術後の遊離型分画值の 総量分画值に対する割合は F はほとんどの例で， E は大部分の例で増加したが， THF は軽度減少する傾向を示し，THE は全例不変であつた．乙れらの結果侵襲時でのF， Eのグルクロ ン酸抱合はそれらの血中レベルの上昇にもかかわらず相対的に抱合されにくいてとを示唆するものであり， THE がその排泄量において遊離型, 総量ともに増加しているにもかかわらず割合が不変であるのは, Engl$\mathrm{ert}^{23)}$ が THE は抱合されやすいと述べているととに一致するでとくで, THE はきわめてすみやが抱合 され，排泄されるようである，乙のととは，舟生ら ${ }^{10) 11)}$ の非ストレス時での cortisol 注入時に $2 \sim 4$ 時間で THE の排泄が最大に達することからもうなずかれる。しかしながら，遊離型 THF の割合が減少する傾 向を示したことは, 相対的には抱合型 THF が増加したというととであり，THEより抱合され難いとは言 $亢^{23)}$ ，侵襲時では cortisol の代謝が非ストレス時での $\mathrm{F} \rightarrow \mathrm{E} \rightarrow \mathrm{THE}$ の経路より $\mathrm{F} \rightarrow \mathrm{THF}$ の代謝経路へ相 対的に推移するものと考察され, 総量分画で侵襲が高度になるにつれ, THE, THF, F の順で尿中排泄が 増加してゆくことからもうなずかれる ${ }^{6) \sim 9)}$.

\section{結語}

各種の手術が行なわれた10例について, 術前後の尿中遊離型 17-OHCS とその分画量わよび総 17-OHCS 量とその分画量を測定測定し，次の結果を得た.

（1） 遊離型量は対照時で $0.06 〜 1.16 \mathrm{mg} / \mathrm{day}$ の排泄量を示し, 総量の増加に一致して増加したが, 術中の cortisol 注入例を除き総量に対する割合はあまり変化しなかつた.

（2）遊離型分画の対照時での排泄量は 4 分画とも $0.05 \mathrm{mg} / \mathrm{day}$ 前後のほぼ均等量を示した. 総量分画に対 する割合は cortisol, cortisone は数10\%を占めるに反し, THF, THE は数\%にすぎなかつた.

(3) tetrahydro 型の一部がグルクロン酸抱合を受けずに排泄 されるとと，および cortisol, cortisone の グルクロン酸抱合が明らかであつた.

（4）術後の遊離型分画の排泄量は，4 分画とも増加したが，特に cortisol の増加が著明で総量分画とは 量的，質的に全く異る排泄パターンを示した.

(5) 総量分画と同様, cortisol 以外の分画に排泄量の限界が存在した.

（6）術後の総量分画に対する割合は， cortisol, cortisone は増加, THF は軽度減少, THE は不変であり, 前 2 者がストレス時では相対的に抱合され難くなるとと，およびストレス時での cortisol 系への代謝経路の 相対的推移が推察された.

（本論文の要旨は第45回日本内分泌学会総会において発表した。） 
文献

1）梅原千治，佐藤武雄：ステロイドホルモン，V糖質副腎皮質ステロイド，（1967），797，南江堂，東京， 2) Daughaday, W.H. and Mariz, I.K. : Metabolism, $10: 936$, (1961). 3) Beisel, W.R., Raimondo, V.C. and Forsham, P.H. : Ann. Intern. Med., $60: 641$, (1964).

4) 浜中雄二：日内分泌誌, $46: 53$, (1970).

5）魚住 徹, 田中英之, 浜中雄二, 曲直部寿夫, 松本圭史：日本臨床，26： 1999,（1968). 6）工藤茂宣：日内分泌誌， $47 ： 532 ，(1971)$.

7) 工藤茂宣, 寺山百合子, 田村瑞穗, 二川原和男, 白岩康夫, 舟生富寿 : 木と臨床, 20 : 149. (1972).

8）工藤茂宣, 舟生富 寿, 白岩康夫, 田村瑞穂, 寺山百合子, 二川原和男 : 外科, 34:713，(1972). 9) Kudo, S., Funyu, T., Shiraiwa, Y., Tamura, M., Terayama, Y. and Nigawara, K. : Tohoku J. exp. Med., 掲載予定.

10）舟生富寿, 工藤茂宣, 白岩康夫, 田村瑞穗, 寺山百合子, 二川原和男 : 木之臨床, $20:$ No, 9, (1972).

11）舟生富寿, 工藤茂宣, 白岩康夫, 田村瑞穗, 寺山百合子, 二川原和男 : 手術, 掲載予定. 12) 舟生

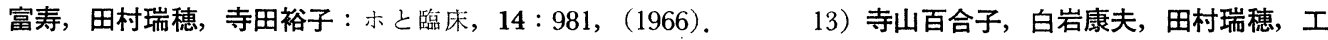
藤茂宣, 新谷洋三, 二川原和男, 舟生富寿 : 木之臨床, $19: 489$, (1971)。 14）舟生富寿, 寺山百合 子, 工藤茂宣, 白岩康夫, 二川原和男 : 小之臨床, $20:$ No, 9, (1972). 15) Kornel, L. and Richardson, S. : Metabolism, $10: 18$, (1961). $\quad$ 16) Brouillet, J.C. and Mattox, V.R. : J. Glin. Endocr., 26 : 453, (1966). $\quad$ 17) Daughaday, W.H., Farr, A. L. and Houghton, E. : Endocrinology, $49: 146$, (1951). 18）栘屋富一, 加藤堅一：臨床酵素学, (1964), 398, 朝倉書店. 19 ) 東 国雄 : 日泌尿会誌，49：50，(1958）。 20）田村瑞穂：日内分泌誌，47：246，（1971）。

Funyu, T., Shiraiwa, Y., Tamura, M., Nigawara, K. and Terada, Y. : Tohoku J. exp. Med., 94 : 377 , (1968). 22) Weichselbaum, T.E. and Margraf, H.W. : J. Glin. Endocr., $19: 1011$, (1959). 23) Englert, E., Brown, M.D., Wallach, S.and Simons, E.L. : J. Glin. Endocr., 17 : 1395, (1957). 